\title{
Comparison of sensorial comfort properties of different cotton fabrics using the Kawabata Evaluation System
}

DOI: $10.35530 / I T .072 .06 .20217$

EMINE UTKUN

\begin{abstract}
REZUMAT
Comparison of sensorial comfort properties of different cotton fabrics using the Kawabata Evaluation System

Cotton fabrics are among the most preferred fabrics for both underwear and outerwear. The sensory comfort properties of the fabrics are important for consumers' choice of clothing. The majority of consumers visually like the clothes that they buy and try to feel these features sensually by touching them, and then, they may want to try the garment or they can make direct purchasing decisions according to these tactile feelings.

In this study, the sensorial properties of a double-layered cotton fabric developed for use as a garment were compared and evaluated with cotton plain woven and interlock fabrics currently used in the market for this purpose. Sensorial comfort properties of the fabrics were researched with KES-F Kawabata equipment.
\end{abstract}

Keywords: sensorial comfort properties, Kawabata Evaluation System, cotton fabrics, clothing comfort, double-layered fabric

\section{Compararea proprietăților de confort senzorial ale diferitelor materiale textile din bumbac folosind sistemul de evaluare Kawabata}

Materialele textile din bumbac sunt printre cele mai preferate, atât pentru lenjerie de corp, cât și pentru îmbrăcămintea exterioară. Proprietățile de confort senzorial ale materialelor textile sunt importante pentru alegerea îmbrăcămintei de către consumatori. Majorității consumatorilor îi plac vizual produsele de îmbrăcăminte pe care le cumpără și încearcă să simtă aceste trăsături atingându-le, iar apoi, ar putea dori să probeze sau să ia decizii directe de cumpărare în funcție de aceste simțuri tactile.

În acest studiu, proprietățile senzoriale ale unei țesături duble de bumbac realizată pentru a fi utilizată pentru articole de îmbrăcăminte au fost comparate și evaluate cu țesătură cu legatura pânză și cu tricot cu structura interlock din bumbac, utilizate în prezent pe piață în acest scop. Proprietățile de confort senzorial ale materialelor textile au fost investigate cu echipamente KES-F Kawabata.

Cuvinte-cheie: proprietăți de confort senzorial, sistem de evaluare Kawabata, materiale textile din bumbac, confortul articolelor de îmbrăcăminte, țesătură dublă

\section{INTRODUCTION}

Clothing is an inseparable part of human life. Clothing comfort can be defined as when a person feels physiologically, psychologically and physically balanced and pleased in that clothes under the current ambient conditions. Clothing comfort is an important factor in the stage where people make their clothing selection. Researches on this subject are valuable for increasing people's living standards [1-3].

Clothing comfort is divided into sub-components as thermal, sensorial (tactile), body movement and psychological (aesthetical) comfort [4].

The sensorial comfort of a fabric has multidimensional properties and is not possible by measuring a single physical property. The concept of "fabric handle" is generally used to evaluate the sensory or tactile comfort properties of fabrics [5].

Although the fabric handle is difficult to define precisely, it is accepted as a comprehensive assessment method that enables the perception of textile materials with the sense of touch thanks to physical stimuli, one of the mechanical properties [6].

The best known, most remarkable and most modern method among the objective evaluation methods of fabric handle is the Kawabata Evaluation System (KES-FB) which has developed by Kawabata and her team in Japan [2, 6-10].

The Hand Evaluation Standardization Committee (HESC) has been established at the Kyoto University, Japan in 1972, for making a definition of "handle". Professor Sueo Kawabata developed the "Kawabata Evaluation System for Fabric" (KES-FB) in collaboration with this Committee [11].

Until now, researchers have used the Kawabata Evaluation System to investigate the tactile properties of fabrics used for different purposes [11-26]. In this research, the sensorial properties of a doublelayered cotton fabric developed for use as a garment were compared and evaluated with cotton plain woven and interlock fabrics currently used in the market for this purpose. 


\section{EXPERIMENTAL PART}

\section{Materials}

In this study, all three cotton samples were manufactured. Sample 1 was a plain fabric, sample 2 was a new-developed double-layered fabric, and sample 3 was an interlock fabric. Sample 1 and 2 were woven on a punched-card dobby loom with 8 frames, and sample 3 was knitted on circular knitting machine.

The details of the test samples, such as, yarn count, density, fibre type, fabric construction, texture report and knitting type are given in tables 1 and 2 .

The determined properties of the fabrics, such as square mass and thickness are presented in table 3.

\section{Method}

All the experimental studies were performed in the Textile Laboratories in the Department of Materials Science, in Fibre Materials at Tampere University of Technology. All the fabric samples were conditioned under the temperature of $(20 \pm 2)^{\circ} \mathrm{C}$ and relative humidity of $(65 \pm 5) \%$ for at least 24 hours before the experimental studies which were conducted in the same conditions.

Sensorial comfort properties were measured on KES-F Kawabata instruments according to "The Standardization and Analysis of Hand Evaluation" procedure.

Characteristic values of KES-F system are given in table 4 [27]. The sixteen characteristic values were calculated from the Kawabata instruments. All measurements, except compression, were made both in machine (warp) and in cross (weft) directions on face side. The size of one test piece was $200 \mathrm{~mm} \times 200$ $\mathrm{mm}$. Four parallel tests were made for each sample in all Kawabata tests.

\section{RESULTS AND DISCUSSION}

\section{KES-FB-1 Tensile}

The test piece was stretched to the maximum load of $500 \mathrm{gf} / \mathrm{cm}$ with a speed of $0.2 \mathrm{~mm} / \mathrm{s}$. Determined

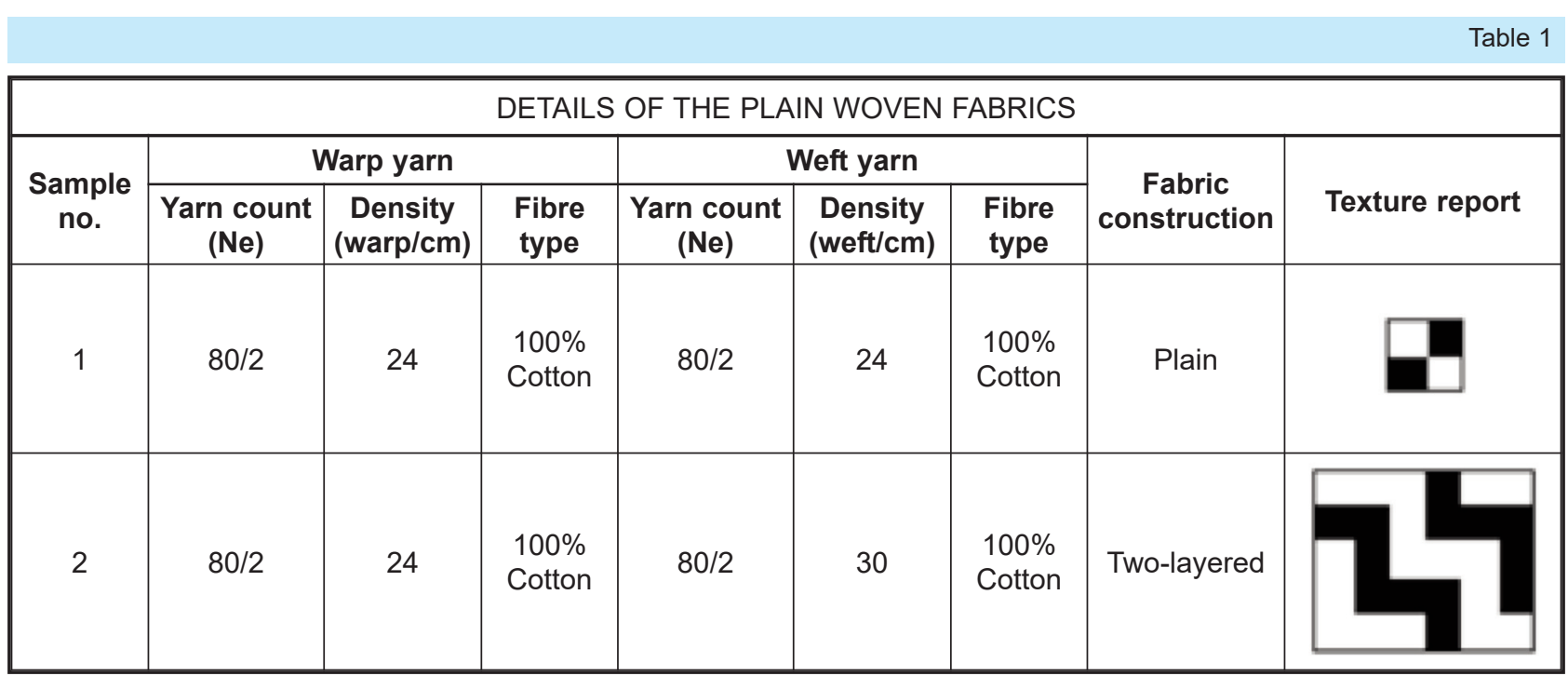

\begin{tabular}{|c|c|c|c|c|c|}
\hline \multicolumn{5}{|c|}{ DETAILS OF THE KNITTED FABRICS } \\
\hline Sample no. & $\begin{array}{c}\text { Yarn count } \\
(\mathrm{Ne})\end{array}$ & Fibre type & $\begin{array}{c}\text { Stitch density } \\
(\text { loops/cm })\end{array}$ & Knitting type & Texture report \\
\hline 3 & $40 / 1$ & $100 \%$ Cotton & 300 & Interlock
\end{tabular}

Table 3

SQUARE MASS AND THICKNESS OF THE FABRICS

\begin{tabular}{|c|c|c|}
\hline Sample no. & $\begin{array}{c}\text { Square mass } \\
\left(\mathbf{g} / \mathbf{m}^{\mathbf{2}}\right)\end{array}$ & $\begin{array}{c}\text { Thickness } \\
(\mathbf{m m})\end{array}$ \\
\hline 1 & 69.1 & 0.32 \\
\hline 2 & 80 & 0.50 \\
\hline 3 & 215.3 & 0.81 \\
\hline
\end{tabular}

tensile values were according to standard settings (KES sensitivity $5 \times 5$, tensile preset 2.0 , sample width of $20 \mathrm{~cm}$ and sample length $5 \mathrm{~cm}$ ) for all the samples. LT tensile linearity, WT tensile work, RT tensile resilience and EMT elongation at maximum load were calculated in machine and cross directions. These results are presented in tables 5 and 6 .

A low value of tensile linearity, LT means load extension curve is not linear. In other words, if value is 


\begin{tabular}{|c|c|c|c|}
\hline \multicolumn{4}{|c|}{ CHARACTERISTIC VALUES OF KES-F SYSTEM } \\
\hline Property & Symbol & Characteristic value & Unit \\
\hline \multirow{3}{*}{ Tensile } & LT & Linearity & - \\
\hline & WT & Tensile energy & gf.cm/ $/ \mathrm{cm}^{2}$ \\
\hline & RT & Resilience & $\%$ \\
\hline \multirow{2}{*}{ Bending } & $B$ & Bending rigidity & gf. $\mathrm{cm}^{2} / \mathrm{cm}$ \\
\hline & $2 \mathrm{HB}$ & Hysteresis of bending moment & gf.cm/cm \\
\hline \multirow{3}{*}{ Shearing } & $\mathrm{G}$ & Shear stiffness & $\mathrm{gf} / \mathrm{cm}^{\circ}$ \\
\hline & $2 \mathrm{HG}$ & Hysteresis of shear force at $0,5^{\circ}$ shear angle & $\mathrm{gf} / \mathrm{cm}$ \\
\hline & $2 \mathrm{HG} 5$ & Hysteresis of shear force at $5^{\circ}$ shear angle & $\mathrm{gf} / \mathrm{cm}$ \\
\hline \multirow{3}{*}{ Compression } & LC & Linearity & - \\
\hline & WC & Compressional energy & gf.cm/ $\mathrm{cm}^{2}$ \\
\hline & $\mathrm{RC}$ & Resilience & $\%$ \\
\hline \multirow{3}{*}{ Surface } & MIU & Coefficient of friction & - \\
\hline & MMD & Mean deviation of MIU & - \\
\hline & SMD & Geometrical roughness & micron \\
\hline \multirow{2}{*}{ Weight \& Thickness } & W & Weight per unit area & $\mathrm{mg} / \mathrm{cm}^{2}$ \\
\hline & $\mathrm{T}$ & Thickness at $0,5 \mathrm{gf} / \mathrm{cm}^{2}$ & $\mathrm{~mm}$ \\
\hline
\end{tabular}

\begin{tabular}{|c|c|c|c|c|c|c|c|c|}
\hline \multicolumn{9}{|c|}{ MEASUREMENT RESULTS OF TENSILE TESTS FOR LT TENSILE LINEARITY AND WT TENSILE WORK } \\
\hline $\begin{array}{c}\text { Sample } \\
\text { no. }\end{array}$ & LT machine & $\begin{array}{l}\text { CV } \\
(\%)\end{array}$ & LT cross & $\begin{array}{l}\text { CV } \\
(\%)\end{array}$ & $\begin{array}{l}\text { WT machine } \\
\left(\mathrm{gf} . \mathrm{cm} / \mathrm{cm}^{2}\right)\end{array}$ & $\begin{array}{l}\text { CV } \\
(\%)\end{array}$ & $\begin{array}{l}\text { WT cross } \\
\left(\mathrm{gf} . \mathrm{cm} / \mathrm{cm}^{2}\right)\end{array}$ & $\begin{array}{l}\text { CV } \\
(\%)\end{array}$ \\
\hline 1 & 0.581 & 2.60 & 0.555 & 2.26 & 8.683 & 5.93 & 8.351 & 2.86 \\
\hline 2 & 0.567 & 3.18 & 0.472 & 4.77 & 5.897 & 3.68 & 8.139 & 2.21 \\
\hline 3 & 0.687 & 4.59 & 0.796 & 5.60 & 41.284 & 2.94 & 98.957 & 2.09 \\
\hline
\end{tabular}

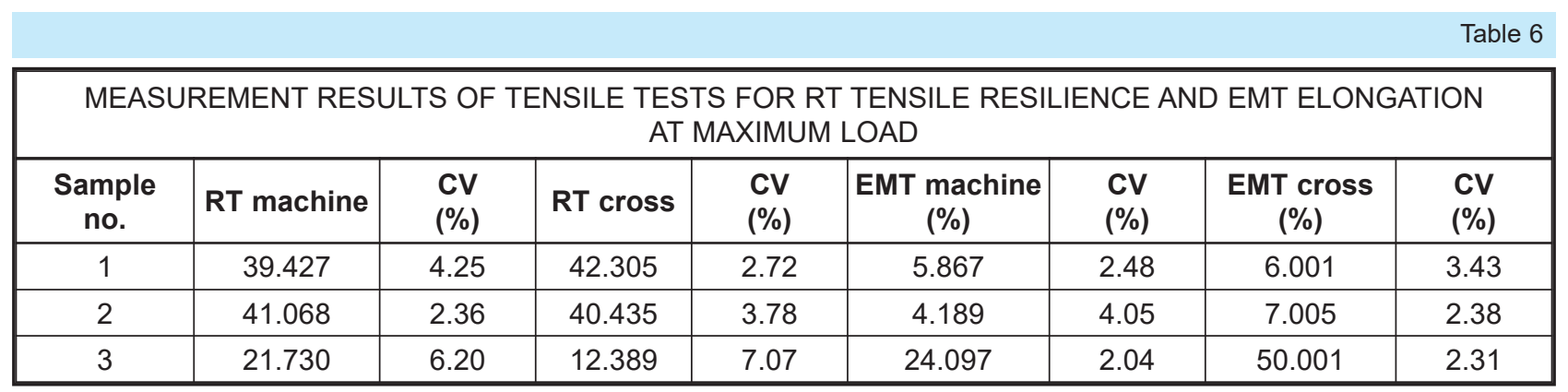

high, the curve is near to the straight line $[28,29]$. LT is indicative of clothing comfort. Lower values of LT show higher fabric extensibility, and better comfort [15]. The values range from 0.567 to 0.687 in machine direction and from 0.472 to 0.796 in cross direction. The lowest values were measured from sample 2 in both directions. The highest values were measured from the knitted sample 3 in both directions.

Tensile work, WT, is the energy required for extending the fabric. High value means higher energy, and low value represents lower energy [28, 29]. The modified twill sample 2 had the lowest values in both directions and the knitted sample 3 had the highest values in both directions.
Tensile resilience, RT, means the ability of fabric recovery after applying the tensile stress. A low value means that recovering the original shape after removing the applied tensile stress is difficult for the fabric $[28,29]$. The lowest values were measured from the knitted sample 3 in both directions. The highest value was measured from sample 2 in machine direction and sample 1 in cross direction.

Elongation at maximum load, EMT, is the percentage of elongation of the fabric from the beginning to the applying tensile stress. High elongation at maximum load value means that high extension at maximum load, low elongation at maximum load value means that low extension at maximum load [28, 29]. In other words, EMT states extensibility of the fabric. The 
fabric is required to have sufficient extensibility in garment production [12, 15]. The highest values were measured from sample 3 in both directions. The lowest value in machine direction was measured from sample 2 and in cross direction from sample 1.

\section{KES-FB-2 Bending rigidity}

The settings were made according to the thickness of the samples. All the fabrics were thin, and KES sensitivity $2 \times 1$ and sample width of $20 \mathrm{~cm}$ were used for all the samples. The results of bending rigidity $B$ and hysteresis $2 \mathrm{HB}$ are given in table 7 in machine and cross directions. Machine direction refers warp direction and cross direction refers weft direction. Test piece was bended first to the warp and then to the weft direction. The average for forward and backward bending was calculated.
The hysteresis of bending moment $2 \mathrm{HB}$ represents the recovery ability of the fabric after bending. If the value of $2 \mathrm{HB}$ is low, return curve follows near the bending curve. In other words, the fabric recovers easily after bending. If the value of $2 \mathrm{HB}$ is high, return curve deviates significantly from the bending curve thus; the fabric recovers with difficulty after bending $[28,29]$. A lower value of $2 \mathrm{HB}$ is better [24]. In machine and cross directions, the lowest hysteresis of bending moment value was measured from sample 1.

Sample 1 and 2 were woven fabrics and they bend and recover easily in weft direction, it might be due to the weaving process. Warp yarns were more stable than weft yarns on the shuttle loom during the weaving. Warp yarns were fixed on the shuttle loom, however weft yarns were moving. Sample 3 was a knitted

Table 7

\begin{tabular}{|c|c|c|c|c|c|c|c|c|}
\hline \multicolumn{9}{|c|}{ MEASUREMENT RESULTS OF BENDING RIGIDITY TESTS } \\
\hline $\begin{array}{c}\text { Sample } \\
\text { no. }\end{array}$ & $\begin{array}{l}\text { B machine } \\
\left(\mathrm{gf} . \mathrm{cm}^{2} / \mathrm{cm}\right)\end{array}$ & $\begin{array}{l}\text { CV } \\
(\%)\end{array}$ & $\begin{array}{c}\text { B cross } \\
\left(\mathrm{gf} . \mathrm{cm}^{2} / \mathrm{cm}\right)\end{array}$ & $\begin{array}{l}\text { CV } \\
(\%)\end{array}$ & $\begin{array}{l}\text { 2HB machine } \\
\text { (gf. } \mathrm{cm} / \mathrm{cm})\end{array}$ & $\begin{array}{l}\text { CV } \\
(\%)\end{array}$ & $\begin{array}{l}\text { 2HB cross } \\
\text { (gf.cm/cm) }\end{array}$ & $\begin{array}{l}\text { CV } \\
(\%)\end{array}$ \\
\hline 1 & 0.024 & 8.15 & 0.022 & 8.30 & 0.018 & 10.89 & 0.015 & 16.42 \\
\hline 2 & 0.053 & 6.75 & 0.033 & 5.21 & 0.037 & 10.13 & 0.021 & 18.89 \\
\hline 3 & 0.072 & 4.57 & 0.019 & 6.08 & 0.057 & 7.30 & 0.025 & 10.63 \\
\hline
\end{tabular}

Low bending rigidity $(B)$ value means that fabric bends easily. High bending rigidity $(B)$ value means that fabric resists bending [28, 29]. Bending rigidity $(B)$ is a measure, which influence the sewability of the fabrics. The lower the bending rigidity, the lower is a fabric's ability to resist when it is bent by exterior forces that may occur during manufacturing processes $[12,15]$. The values were in range of $0.024-0.072$ in machine direction and $0.019-0.033$ in cross direction. In machine direction, the lowest rigidity value was measured from sample 1. In cross direction, the lowest rigidity values were measured from sample 3 . Thickness is also important for this property, so correlation analysis was performed between bending rigidity and thickness of the samples (table 8). There was an excellent relationship between $B$ machine and thickness value. It means that when the thickness of the sample increases, so does the bending value in the machine direction. In addition, there was a negative fair degree of relationship between $B$ cross and thickness value.

Table 8

\begin{tabular}{|c|l|c|c|}
\hline \multicolumn{2}{|c|}{$\begin{array}{c}\text { CORRELATION MATRIX } \\
\text { OF BENDING RIGIDITY }\end{array}$} & $\begin{array}{c}\text { B machine } \\
\text { (gf.cm } \mathbf{~} / \mathbf{c m})\end{array}$ & $\begin{array}{c}\text { B cross } \\
\text { (gf.cm } \mathbf{~} / \mathbf{c m})\end{array}$ \\
\hline \multirow{2}{*}{$\begin{array}{c}\text { Thickness } \\
(\mathrm{mm})\end{array}$} & $\begin{array}{l}\text { Pearson } \\
\text { Correlation }-\mathrm{r}\end{array}$ & 0.963 & -0.349 \\
\cline { 2 - 4 } & Sig. (2-tailed) & 0.173 & 0.773 \\
\cline { 2 - 4 } & $\begin{array}{l}\text { Number of } \\
\text { Samples }\end{array}$ & 3 & 3 \\
\hline
\end{tabular}

Note: Correlation is significant at the 0.01 level (2-tailed). fabric and it bends and recovers easily in weft direction, too. It may be due to the knitting process. In knitting process of sample 3 , loops were produces in the weft direction one by one, respectively.

\section{KES-FB-1 Shear}

Shear values were measured on the same Kawabata instrument (KES-FB1) as the tensile values. Shear values were obtained according to standard settings (KES sensitivity $2 \times 5$, sample width $20 \mathrm{~cm}$, sample length $5 \mathrm{~cm}$, shearing angles $\pm 8^{\circ}$ ) for all the samples. The sample was placed between jaws, and back jaws moved maximum $8^{\circ}$ in side direction to the left, and then returned to the beginning position. The applied shear deformation was $10 \mathrm{gf} / \mathrm{cm}$ [28].

The shearing stiffness $\mathrm{G}$ and the hysteresis values at shearing angles of $0.5^{\circ}(2 \mathrm{HG})$ and of $5^{\circ}(2 \mathrm{HG} 5)$ are given in both directions in table 9 .

If shear stiffness value is low, the sample is easy to shear and it resists shearing while the value is high $[28,29]$. Shear deformation is very important during wearing since the fabric needs to be stretched or sheared, so it affects body movement comfort. This property is also substantial during the garment manufacture. If the shear stiffness is not enough, fabric will defect easily. If it is too high, such problems, like forming, moulding, or shaping can be seen [12]. The values ranged from $0.156 \mathrm{gf} / \mathrm{cm}^{\circ}$ to $0.821 \mathrm{gf} / \mathrm{cm}^{\circ}$ in machine direction and from $0.150 \mathrm{gf} / \mathrm{cm}^{\circ}$ to 0.812 $\mathrm{gf} / \mathrm{cm}^{\circ}$ in cross direction. The highest values were measured from sample 3 in both directions. The lowest values were measured from sample 2 in both directions. The modified twill sample 2 had higher 


\begin{tabular}{|c|c|c|c|c|c|c|c|c|c|c|c|c|}
\hline \multicolumn{13}{|c|}{ MEASUREMENT RESULTS OF SHEAR TESTS } \\
\hline $\begin{array}{c}\text { Sample } \\
\text { no. }\end{array}$ & $\begin{array}{c}\text { G } \\
\text { machine } \\
\left(\mathrm{gf}^{\prime} / \mathrm{cm}^{\circ}\right)\end{array}$ & $\begin{array}{l}\text { CV } \\
(\%)\end{array}$ & $\begin{array}{l}\text { G cross } \\
\left(\mathrm{gff}^{\circ} / \mathrm{cm}^{\circ}\right)\end{array}$ & $\begin{array}{l}\text { CV } \\
(\%)\end{array}$ & $\begin{array}{c}2 H G \\
\text { machine } \\
(\mathrm{gf} / \mathrm{cm})\end{array}$ & $\begin{array}{l}\text { CV } \\
(\%)\end{array}$ & $\begin{array}{c}2 \mathrm{HG} \\
\text { cross } \\
\text { (gf/cm) }\end{array}$ & $\begin{array}{l}\text { CV } \\
(\%)\end{array}$ & $\begin{array}{c}2 \mathrm{HG5} \\
\text { machine } \\
(\mathrm{gf} / \mathrm{cm})\end{array}$ & $\begin{array}{l}\text { CV } \\
(\%)\end{array}$ & $\begin{array}{c}2 \mathrm{HG5} \\
\text { cross } \\
(\mathrm{gf} / \mathrm{cm})\end{array}$ & $\begin{array}{l}\text { CV } \\
(\%)\end{array}$ \\
\hline 1 & 0.402 & 10.784 & 0.237 & 4.55 & 0.053 & 7.04 & 0.509 & 9.33 & 0.526 & 11.19 & 0.853 & 2.78 \\
\hline 2 & 0.156 & 5.788 & 0.150 & 4.12 & 0.144 & 3.02 & 0.248 & 2.64 & 0.285 & 4.90 & 0.451 & 3.42 \\
\hline 3 & 0.821 & 2.239 & 0.812 & 3.25 & 3.512 & 6.86 & 4.587 & 6.91 & 4.409 & 9.23 & 5.589 & 5.35 \\
\hline
\end{tabular}

shear stiffness in machine direction than in cross direction.

If the value of hysteresis at $0.5^{\circ}, 2 \mathrm{HG}$ is low, the return curve goes nearby the shear curve; therefore the fabric recovers easily after applying the shearing stress. If the value of hysteresis at $0.5^{\circ}, 2 \mathrm{HG}$ is high, the return curve deviates much from the shear curve. In other words the recovery ability of the fabric is poor $[28,29]$. The highest values were for sample 3 in both directions. The lowest value was for sample 1 in machine direction, for sample 2 in cross direction.

For hysteresis at $5^{\circ}, 2 \mathrm{HG} 5$, a low value refers that the return curve does not deviate much more from the shear curve and the fabric recovers easily from shearing $[28,29]$. Sample 3 had the highest value in both directions. Sample 2 had the lowest values in both directions.

The knitted sample 3 had higher shearing stiffness, the hysteresis values at shearing angles of $0,5^{\circ}$ and of $5^{\circ}$ than the woven fabrics 1,2 . In addition, for all the samples the hysteresis values at shearing angles of $0,5^{\circ}$ in cross direction were higher than in machine direction. The biggest difference was in sample 1.

\section{KES-FB-3 Compression}

Compression values were determined according to standard settings (KES sensitivity $2 \times 5$, compression force $50 \mathrm{gf} / \mathrm{cm}^{2}$, compression speed $1 \mathrm{~mm} / 50 \mathrm{~s}$, sample width $20 \mathrm{~cm}$ ) for all the samples. The results are given in table 10 .

Fabric compression is highly related to fabric handle, softness and surface smoothness [12].

If compressibility value, EMC is low, the fabric compressibility is low or if compressibility value, EMC is high, the fabric compressibility is high. If a material is harder and denser, it can be compressed less $[28,29]$. Sample 1 was the most and sample 3 was the least compressible. According to our results, it is obvious that as the weight and thickness of the fabric increases; the compressibility decreases (tables 3 and 10).

A high value of linearity, LC, means that the compression curve does not deviate remarkably from a straight line, therefore it is linear, and low value means that it deviates significantly $[28,29]$. Sample 1 had the lowest value and sample 2 had the highest value.

Compression energy, WC, with a high value means compression needs high-energy supply, and a low value means compression needs low-energy supply $[28,29]$. The lowest value was noted for sample 1 and the highest value for sample 2 .

Compressional resilience value, $\mathrm{RC}$, shows the ability to recover of the fabric after the compression deformation. The low value refers the retention ability of deformation after compression is good. In other words, the high value refers the ability to recover is poor $[28,29]$. Sample 3 had the lowest value and sample 2 had the highest value.

\section{KES-FB-4 Surface friction}

Surface friction values were determined according to standard settings (KES sensitivity $2 \times 5$ and sample size of $200 \mathrm{~mm} \times 200 \mathrm{~mm}$ ) for all the samples. In addition, when preparing the experimental setup to place the fabric on the instrument, for sample 3 , it was used $80 \mathrm{gf}$ weight and, for samples 1, 2 it was used $200 \mathrm{gf}$ weight. Weights were adjusted according to the thickness of the samples. A five-millimetre wide metal "finger" sensor, with a similar surface as human fingertip, was used for the measure.

Samples were moving by a constant speed of 0.1 $\mathrm{cm} / \mathrm{s}$ on a horizontal smooth steel plate between $2 \mathrm{~cm}$ interval in surface friction and roughness tests [26]. It is well known that the handle of the fabrics is closely related to the surface properties. There were wrinkles on the surface of the woven test samples. Because they had been washed in water but they

Table 10

\begin{tabular}{|c|c|c|c|c|c|c|c|c|c|c|c|c|}
\hline \multicolumn{13}{|c|}{ MEASUREMENT RESULTS OF COMPRESSION TESTS } \\
\hline $\begin{array}{c}\text { Sample } \\
\text { no. }\end{array}$ & LC & $\begin{array}{l}\text { CV } \\
(\%)\end{array}$ & $\begin{array}{c}W C \\
\text { (gf.cm/cm²) }\end{array}$ & $\begin{array}{l}\text { CV } \\
(\%)\end{array}$ & $\begin{array}{l}\text { RC } \\
(\%)\end{array}$ & $\begin{array}{l}\text { CV } \\
(\%)\end{array}$ & $\begin{array}{c}\mathrm{T0} \\
(\mathrm{mm})\end{array}$ & $\begin{array}{l}\text { CV } \\
(\%)\end{array}$ & $\underset{(\mathrm{mm})}{\mathrm{Tm}}$ & $\begin{array}{l}\text { CV } \\
(\%)\end{array}$ & $\begin{array}{c}\text { EMC } \\
(\%)\end{array}$ & $\begin{array}{l}\text { CV } \\
(\%)\end{array}$ \\
\hline 1 & 0.228 & 5.96 & 0.228 & 3.45 & 49.617 & 2.29 & 0.501 & 7.13 & 0.189 & 3.95 & 62.395 & 5.12 \\
\hline 2 & 0.361 & 7.61 & 0.352 & 3.78 & 52.298 & 1.52 & 0.713 & 3.51 & 0.426 & 5.29 & 40.343 & 9.26 \\
\hline 3 & 0.320 & 2.4 & 0.333 & 2.21 & 35.975 & 2.19 & 1.131 & 2.26 & 0.752 & 1.54 & 33.569 & 2.39 \\
\hline
\end{tabular}




\begin{tabular}{|c|c|c|c|c|c|c|c|c|}
\hline \multicolumn{10}{|c|}{ MEASUREMENT RESULTS OF FRICTION TESTS } \\
\hline $\begin{array}{c}\text { Sample } \\
\text { no. }\end{array}$ & $\begin{array}{c}\text { MIU } \\
\text { machine }\end{array}$ & $\begin{array}{c}\text { CV } \\
(\%)\end{array}$ & MIU cross & $\begin{array}{c}\text { CV } \\
(\%)\end{array}$ & $\begin{array}{c}\text { MMD } \\
\text { machine }\end{array}$ & $\begin{array}{c}\text { CV } \\
(\%)\end{array}$ & MMD cross & $\begin{array}{c}\text { CV } \\
(\%)\end{array}$ \\
\hline 1 & 0.191 & 2.15 & 0.174 & 1.65 & 0.025 & 13.47 & 0.030 & 8.07 \\
\hline 2 & 0.243 & 5.15 & 0.202 & 7.27 & 0.033 & 6.77 & 0.024 & 17.94 \\
\hline 3 & 0.206 & 2.59 & 0.217 & 1.71 & 0.010 & 9.34 & 0.018 & 4.54 \\
\hline
\end{tabular}

were not ironed not to damage them. On the other hand, knitted sample was finished under the relevant commercial production conditions, thus there weren't any wrinkles on their surface. This is the important point for surface properties, friction and roughness. The sensor was very sensitive and these wrinkles may have influence on the results.

The frictional coefficient MIU and mean deviation of MIU, MMD, are given in both directions in table 11.

A low value for MIU coefficient means low friction and a high value means high friction [28, 29]. The values ranged from 0.191 to 0.243 in machine direction and from 0,174 to 0,217 in cross direction. The lowest values were measured from sample 1 in both directions. The highest value in machine direction was measured from sample 2 and in cross direction from sample 3.

A low value for MMD, mean deviation of MIU, refers an even friction coefficient, and a high value refers an uneven friction coefficient $[28,29]$. The lowest value was recorded from sample 3 in both directions. The highest value was recorded from sample 2 in machine direction, from sample 1 in cross direction.

\section{KES-FB-4 Surface roughness}

Surface friction values were determined according to standard settings (KES sensitivity $2 \times 5$ and sample size of $200 \mathrm{~mm} \times 200 \mathrm{~mm}$ ) for all the samples. Surface roughness values were measured on the same Kawabata instrument (KES-FB4) as friction. However, measuring sensor was different, a $U$-shaped metal wire (5 $\mathrm{mm}$ wide).

Geometrical roughness SMD values are presented in both directions in table 12 .

Table 12

MEASUREMENT RESULTS OF SURFACE ROUGHNESS TESTS

\begin{tabular}{|c|c|c|c|c|}
\hline $\begin{array}{c}\text { Sample } \\
\text { no. }\end{array}$ & $\begin{array}{c}\text { SMD } \mu \\
\text { machine }\end{array}$ & $\begin{array}{c}\text { CV } \\
\text { (\%) }\end{array}$ & $\begin{array}{c}\text { SMD } \mu \\
\text { cross }\end{array}$ & $\begin{array}{c}\text { CV } \\
\text { (\%) }\end{array}$ \\
\hline 1 & 8.463 & 2.46 & 7.166 & 2.46 \\
\hline 2 & 11.751 & 2.85 & 14.197 & 5.61 \\
\hline 3 & 1.102 & 1.32 & 3.945 & 2.00 \\
\hline
\end{tabular}

If geometrical roughness value is low, the surface of the fabric is smooth or even. In other words, high value of geometrical roughness means an uneven surface $[28,29]$. The values ranged from $1.102 \mu$ to $11.751 \mu$ in machine direction and from 3.945 to
$14.197 \mu$ in cross direction. The roughest was sample 2 in both directions. The smoothest was sample 3 in both directions.

\section{CONCLUSIONS}

Kawabata Evaluation System is a user-friendly instrument to determine total hand value of the fabrics. In other words, it can easily measure tactile properties of the fabrics. These properties are important for the prediction of garment appearance and determination of the problems that may arise in manufacture.

In this study, a double-layered cotton fabric was developed, the sensory properties were investigated by Kawabata Evaluation System, and these properties were compared with one woven and one knitted fabric currently used in the market for clothing.

All of the fabrics are thin and can be used as summer clothes or in hot weather. Underwear, shirts, blouses, baby clothes can be produced from these fabrics. The purpose of developing a double-layer fabric is to obtain a more breathable and softer structure than other fabrics thanks to the presence of air between the layers.

Samples, compared in terms of bending rigidity, shearing stiffness, compressional resilience, frictional coefficient, surface roughness according to their structure, respectively.

Sample 2 was bended as easily as the other fabrics. Stretching of sample 2 fabrics required lower amount of energy than the sample 3 . The woven fabrics were easier to shear than the knitted fabric. The modified twill woven fabric (Sample 2) and knitted fabric (Sample 3) were close each other, and their retention ability of deformation after compression is better than the plain-woven fabric (Sample 1). The frictional coefficient of the woven fabrics (Sample 1,2) and the knitted fabric (Sample 3) were close each other. The surface roughness of the knitted fabric (Sample 3) was even than the woven fabrics (Sample 1,2), but it could be due to the finishing process.

In the light of these findings, it can be concluded that these values of the double layer fabric (Sample 2) are close to or better than the fabrics used in the market and can be used for clothing purposes. It is good enough to serve its function. Additionally, it is thought to have different advantages in terms of thermal comfort as it is double-layered and keeps air between the layers. These properties can be investigated in another study. 


\section{REFERENCES}

[1] Sweeney, M.M., Branson, D.H., Sensorial comfort, part I: a psychophysical method for assessing moisture sensation in clothing, In: Textile Research Journal, 1990, 60, 7, 371-377

[2] Liao, X., Hu J., Li, Y., Li, Q., Wu, X., A review on fabric smoothness-roughness sensation studies, In: Journal of Fiber Bioengineering \& Informatics, 2011, 4, 2, 105-114

[3] Öner, E., Okur, A., Materyal, üretim teknolojisi ve kumaş yapısının termal konfora etkileri, In: Tekstil ve Mühendis, $2010,17,80,20-29$

[4] Li, Y., The Science of Clothing Comfort, In: The Textile Institute Publications, Textile Progress, Manchester, 2001, $31,1 / 2,138$

[5] Makinen, M., Meinander, H., Luible, C., Thalmann, N.M., Influence of physical parameters on fabric hand, In: Proceedings of Haptex '05 - Workshop on Haptic and Tactile Perception of Deformable Objects, University of Hannover, Hannover, Germany, 2005, 8-17

[6] Raheel, M., Liu, J., An emprical model for fabric hand, part I: objective assessment for light weight fabrics, In: Textile Research Journal, 1991, 61, 1, 31-38

[7] Kawabata, S., Niwa, M., High quality fabrics for garments, In: International Journal of Clothing Science and Technology, 1994, 6, 5, 20-25

[8] Kawabata, S., Niwa, M., Yamashita, Y., A guide line for manufacturing "ideal fabrics", In: International Journal of Clothing Science and Technology, 1999, 11, 2/3, 134-140

[9] Park, S.W., Hwang, Y.G., Kang, B.C., Yeo S.W., Applying fuzzy logic and neural networks to total hand evaluation of knitted fabrics, In: Textile Research Journal, 2000, 70, 8, 675-681

[10] Barker, R.L., From fabric hand to thermal comfort: the evolving role of objective measurements in explaining human comfort response to textiles, In: International Journal of Clothing Science and Technology, 2002, 14, 3/4, 181-200

[11] Namligöz, E., Bahtiyari, M., Körlü, A., Çoban, S., Evaluation of Finishing Processes for Linen Fabrics Using the Kawabata Evaluation System, In: Journal of Testing and Evaluation, 2008, 36, 4, 384-391

[12] Chan, C.K., Jiang, X.Y., Liew, K.L, Chan, L.K., Wong, W.K., Lau, M.P., Evaluation of mechanical properties of uniform fabrics in garment manufacturing, In: Journal of Materials Processing Technology, 2006, 174, 1-3, 183-189

[13] Potluri, P., Sagar, T.V., Compaction modelling of textile preforms for composite structures, In: Composite Structures, 2008, 86, 1-3, 177-185

[14] Yip, J., Ng, S.P., Study of three-dimensional spacer fabrics: Physical and mechanical properties, In: Journal of Materials Processing Technology, 2008, 206, 1-3, 359-364

[15] Nayak, R.K., Punj, S.K., Chatterjee, K.N., Behera, B.K., Comfort properties of suiting fabrics, In: Indian Journal of Fibre \& Textile Research, 2009, 34, 122-128

[16] Tsukada, M., Khan, M.M.R., Miura, T., Postle, R., Sakaguchi, A., Mechanical performance of wool fabrics grafted with methacrylamide and 2-hydroxyethyl methacrylate by the Kawabata Evaluation System for Fabric method, In: Textile Research Journal, 2013, 83, 12, 1242-1250

[17] Baig, G.A., Chris, M., Carr, C.M., Kawabata evaluation of PLA-knitted fabric washed with various laundering formulations, In: The Journal of the Textile Institute, 2015, 106, 2, 111-118

[18] Phoophat, P., Kumphai, P., Suwonsichon, S., Boonyarit, J., Plangmon, C., Chollakup, R., Application of Kawabata evaluation system for the tactile properties of woven silk fabrics in textile industry, In: IOP Conf. Series: Materials Science and Engineering, 2020, 773, 1-5

[19] Kawabata, S., Niwa, M., Objective Evaluation of the Quality of Ladies' Garments, In: International Journal of Clothing Science and Technology, 1992, 4, 5, 34-44

[20] Gupta, B.S., Leek, F.J., Barker, R.L., Buchanan, D.R., Little, T.J., Directional Variations in Fabric Properties and Seam Quality, In: International Journal of Clothing Science and Technology, 1992, 4, 2/3, 71-78

[21] Breen, D.E., House, D.H., Wozny, M.J., Predicting the drape of woven cloth using interacting particles, In: SIGGRAPH '94, Proceedings of the 21st annual conference on Computer graphics and interactive techniques, 1994, 365-372

[22] Shishoo, R.L., Importance of mechanical and physical properties of fabrics in the clothing manufacturing process, In: International Journal of Clothing Science and Technology, 1995, 7, 2/3, 35-42

[23] Eberhardt, B., Weber, A., Strasser, W., A fast, flexible, particle-system model for cloth draping, In: IEEE Computer Graphics and Applications, 1996, 16, 5, 52-59

[24] Behera, B.K., Ishtiaque, S.M., Chand, S., Comfort Properties of Fabrics Woven from Ring-, Rotor-, and Frictionspun Yarns, In: Journal of the Textile Institute, 1997, 88, 3, 255-264

[25] Jiang, Y., Hu, J., Ko, F., Characterizing and Modeling Bending Properties of Multiaxial Warp Knitted Fabrics, In: Textile Research Journal, 1999, 69, 9, 691-697

[26] Tao, W., Calamari, T.A., Yu, C., Chen, Y., Preparing and Characterizing Kenaf/Cotton Blended Fabrics, In: Textile Research Journal, 1999, 69, 10, 720-724

[27] Kawabata, S., The Standardization and Analysis of Hand Evaluation, $2^{\text {nd }}$. Edition, The Hand Evaluation and Standardization Committee, The Textile Machinery Society of Japan, 1980, 96 
[28] Peltonen, C., Comfort Properties in Multifunctional Protective Clothing, Master of Science Thesis, Tampere University of Technology, Finland, 2011, 86

[29] Varheenmaa, M., MOL-9806:2012-Clothing Manufacture and Physiology Course Notes, Tampere University of Technology, Automation, Mechanical and Materials Engineering, Fiber Material Science, Finland, 2012

\section{Author:}

EMINE UTKUN

Pamukkale University, Buldan Vocational Training School, Program of Fashion Design, Denizli, 20400, Turkey

\section{Corresponding author:}

EMINE UTKUN

e-mail: eutkun@pau.edu.tr 